DOI: https://doi.org/10.32689/2618-0065-2020-2(4)-45-51

Богданенко Анатолій Іванович, кандидат наук з державного управління, доктор економічних наук, доцент кафедри публічного адміністрування, Міжрегіональна Академія управління персоналом, 03039, м. Київ, вул. Фрометівська, 2, тел.: (044) 264-52-54, e-mail: Anatoliy_Bogdanenko@ukr.net, https//orcid.org/0000-0003-0758-5809

\title{
ОСНОВНІ ПОНЯТТЯ ТА ВИЗНАЧЕННЯ ДЕРЖАВНОГО РЕГУЛЮВАННЯ ІНВЕСТИЦЙНИМИ ПРОЦЕСАМИ У СФЕРІ БУДІВНИЦТВА СОЦАЛЬНОГО ЖИТЛА
}

Анотація. Вирішення покращення житлових умов громадян уряди країн використовують як важливий інструмент у намаганнях досягнути поставлених цілей соціального характеру у суспільстві. Адже рівень забезпеченості громадян належними житловими умовами говорить про успішність державної політики. Цей показник навіть більш інформативний та відчутний для громадян, аніж показник економічного зростання країни згідно офіційної урядової статистики. Тож, якщо рівень добробуту населення визначено як високий, то можна судити про те, що проблема забезпечення житлом своїх громадян $є$ не найбільш гострою 3-поміж усіх інших.

На жаль, для України, де величезні черги на отримання житла існують вже понад 30 років, питання житлового забезпечення малозабезпечених та незахищених громадян $\epsilon$ надзвичайно болючим. Однак, у багатьох європейських країнах система житлового забезпечення громадян давно врегульована та налагоджена, а уряди держав приймають активну участь у цьому процесі. Тож, державне регулювання інвестиційними процесами у будівництві житла для соціально незахищених громадян $є$ вкрай важливим та має стати одним з пріоритетних напрямів державної політики України. А 3 пізнавальної точки зору пошук шляхів розв'язання цих проблем становить неабиякий суспільний та науковий інтерес.

На даний час проблема будівництва соціального житла загострилась через недосконалість фінансово-кредитної системи, процесу централізації будівництва, реконструкції та утримання житлового фонду, обмеження у виділенні земельних ділянок і спорудженні індивідуального житла, відсутність стимулюючих факторів у вирішенні житлових питань тощо.

Саме тому реалізація соціальної житлової політики повинна сприяти створенню умов для покращення якості життя населення за рахунок впровадження соціальних стандартів, формування оптимальної мережі 
закладів соціальної інфраструктури, цільового спрямування інвестицій в їх подальший розвиток і підвищення якості будівельних послуг.

Ключові слова: державне регулювання інвестиційними процесами, будівництво соціального житла, інвестиційна політика у будівництві, інвестиційна діяльність, державна політика України.

Bogdanenko Anatoliy Ivanovych, Ph.D. in public administration, Doctor of Science in Economics, Associate Professor of Public Administration Department, Interregional Academy of Personnel Management, 2, Frometivska st., 03039, Kyiv, phone: (044) 264-52-54, e-mail: Anatoliy_Bogdanenko@ukr.net, https//orcid.org/0000-0003-0758-5809

\section{BASIC CONCEPTS AND DEFINITION OF STATE REGULATION OF INVESTMENT PROCESSES IN THE SOCIAL HOUSING BUILDING}

Annotation. The governments of the countries use the solutions to improve the living conditions of the citizens as an important tool in the pursuit of social goals in society. After all, the level of providing citizens with adequate living conditions indicates the success of the public policy. This indicator is even more informative and sensitive to citizens than the economic growth indicator of the country according to official government statistics. Therefore, if the level of well-being of the population is defined as high, then it can be measured that the problem of providing housing for its citizens is not the most acute among all others.

Unfortunately, for Ukraine, where there have been huge queues for housing for over 30 years, the issue of housing for poor and most vulnerable citizens is extremely painful. However, in many European countries, the housing system for citizens has long been regulated and established, and governments are taking an active part in this process. Therefore, state regulation of investment processes in housing construction for socially vulnerable citizens is of utmost importance and should become one of the priority directions of the state policy of Ukraine. And from a cognitive perspective, finding ways to solve these problems is of great public and scientific interest.

At present, the problem of construction of social housing is exacerbated by the imperfection of the financial and credit system, the process of centralization of construction, reconstruction and maintenance of housing stock, restrictions in the allocation of land and construction of individual housing, the lack of stimulating factors in addressing housing issues.

That is why the implementation of social housing policy should help to create conditions for improving the quality of life of the population through the introduction of social standards, the formation of an optimal network of social infrastructure institutions, targeted investment in their further development and improving the quality of construction services. 
Keywords: state regulation of investment processes, social housing construction, investment policy in construction, investment activity, the state policy of Ukraine.

Постановка проблеми. Соціальна житлова політика в державі повинна допомагати сім'ям, які не можуть дозволити собі нормальні умови проживання. Саме тому реалізація соиіальної житлової політики повинна сприяти створенню умов для покращення якості життя населення, за рахунок впровадження соціальних стандартів, формування оптимальної мережі закладів соціальної інфраструктури, цільового спрямування інвестицій в їх подальший розвиток і підвищення якості будівельних послуг. Соціальна спрямованість розвитку житлового будівництва передбачає ефективне функціонування всіх його підсистем для покращення рівня і якості життя населення, як це відбувається у країнах Європейського Союзу та інших розвинених державах. Насамперед, потрібно виокремити основні пріоритети для сталого розвитку процесу забезпечення населення України соціальним житлом та основні завдання для їх реалізації, з урахуванням світового досвіду. При цьому, основні зусилля держави щодо вирішення проблем будівництва соціального житла повинні бути спрямовані на створення умов для розв'язання широкого спектру соціально-економічних та політичних проблем, що, зокрема, дасть потужний імпульс розвитку вітчизняної будівельної галузі, що, натомість, позитивно вплине на економіку України загалом.

Аналіз останніх публікацій за проблематикою. Аналіз наукових здобутків свідчить про те, що дослідженню державного регулювання інвестиційних процесів та інвестиційної діяльності у будівництві достатнью уваги приділили фахівці: К. Басенко, М. Вознюк, Н. Клименко, Д. Левчинський, С. Парфенюк, С. Сілюкова, О. Твердь, А. Ткаченко та багато інших. Аспекти державного управління в сфері будівництва соціального житла, можливості забезпечення ним та ін. привертали увагу науковців, таких як Ю. Бондаренко, І. Гнесь, В. Козик, Б. Лисенко, М. Марченко, В. Меленюк, О. Непомнящий, Н. Олійник, В. Омельчук, А. Рябчук, І. Середницька, М. Федорова, Л. Юр'єва та ін., однак питання державного регулювання соціального житлового фонду ще не мають остаточного методологічного та практичного вирішення.

Мета статті. Метою статті $є$ дослідження державного регулювання інвестиційними процесами в будівництві соціального житла як надважливої складової розвитку держави та об'єкту уваги теортетиків та практиків.

Виклад основного матеріалу. Інвестиційний процес у житловому будівництві необхідно вивчати як сукупність послідовно реалізованих процесів будівельно-девелоперськими компаніями щодо формування грошових ресурсів із різних джерел, їх інвестування у проекти будівництва житлових будинків, комплексного освоєння територій з метою отримання інвестиційного 
доходу від їх реалізації і подальшого реінвестування отриманого доходу в нові інвестиційні проекти житлового будівництва.

Отже, інвестиційна сфера є зоною суспільного й економічного розвитку. Через складність завдань інвестиційний процес $є$ складним та специфічним. Його пронизують різноманітні економічні відносини між його учасниками. Тому ми вважаємо, що інвестиційний процес в будівництві соціального житла - це система соціально-економічних відносин 3 приводу розширеного відтворення соціального житлового фонду.

Під інвестиційним проектуванням мають на увазі розробку сукупності технічних документів, що містять технічне та економічне обгрунтування (наявність креслень, пояснювальних записок, бізнес-плану інвестиційного проекту та ін. матеріалів, необхідних для реалізації проекту). Інвестиційне проектування передбачає обов’язкову калькуляцію, за допомогою якої визначається вартість всього інвестиційного проекту. Для того, щоб здійснювати інвестиційну діяльність необхідно нею управляти. Таке управління забезпечується інвестиційним менеджментом.

Інвестиційний менеджмент - «це процес управління всіма сферами інвестиційної діяльності підприємства. Ним передбачається адміністрування всіх функціональних сфер підприємств в питаннях інвестиційної діяльності: фінансів, маркетингу, трудових ресурсів, виробництва» [1].

Підтримати та мотивувати інвестиційну діяльність, щоб вона враховувала суспільні інтереси в державних масштабах, має можливість лише держава, будучи представником інтересів всього суспільства. 3 цих причин в державах і передбачене державне регулювання інвестиційною діяльністю та інвестиційними процесами.

Державне регулювання - управлінський (організуючий) вплив держави. Такий вплив може здійснюватися на сфери та галузі життя, що потребують державного втручання із застосуванням повноважень, якими наділена виконавча влада. Державний управлінський вплив в інвестиційній діяльності здійснюється задля реалізації економічної, науково-технічної та соціальної політики в цій сфері. Про його ефективність свідчать економічний та соціальний розвиток країни. Також про нього можна судити за державними й регіональними програмами розвитку господарства, державними та місцевими бюджетами, обсягами, які передбачені державним бюджетом інвестиційної діяльності.

Державою можуть надаватися певні привілеї. Це пільгові умови для інвесторів, які провадять свою діяльність в напрямах, які $€$ найбільш пріоритетними для задоволення суспільних потреб. Такими є соціальна сфера, технічне й технологічне вдосконалення виробництва, створення нових робочих місць для населення, яке має потребу в соціальному захисті та ін.

«Регулювати - значить додтримуватися певного порядку, правил, упорядковувати, або встановлювати правильну, необхідну для роботи 
взаємодію частин механізму, робити що-небудь для отримання необхідних показників, досягнення потрібного ступеня розвитку, стану чого-небудь. Регулювати хід, рух - означає розмірювати, встановлювати порядок» [2].

Регулюючі дії держави в інвестиційній діяльності та інвестиційних процесах будівництва соціального житла є своєрідною функцією управління, яка направлена на об’єднання інтересів у державі, грунтуючись на прогнозуванні, бюджетному фінансуванні, оподаткуванні, стратегічному плануванні та інших заходах державного регулювання на ринку будівництва соціального житла.

Фахівці державне регулювання інвестиційними процесами визначають як підзаконну, юридично-владну виконавчу та розпорядчу діяльність органів виконавчої влади у здійсненні управлінських функцій, які необхідні в управлінні економічним розвитком держави. Інвестиційна діяльність $\epsilon$ основним напрямом розширення та відтворення основних фондів і виробничих потужностей господарства на базі науково-технічного прогресу. Таким чином, представляється можливість регулювати розвитком економіки, істотно підвищити іiї ефективність, й виходячи 3 цього - вирішити наявні соціальні проблеми (будівництво житлового фонду, об'єктів соціального призначення тощо) [3]. Таке трактування свідчить про його багатоаспектність та дозволяє нам зрозуміти складність процесу регулювання інвестиційної сфери.

Поняття «соціального житла» та «доступного» в Україні часто плутають. Однак це різні поняття. Якщо соціальне житло закріплене в законі України «Про житловий фонд соціального призначення» 2006 р., то статус доступного житла залишається й досі неврегульованим [4].

Соціальне житло входить до спеціального житлового фонду, який має соціальне призначення. Воно передбачене для надання в безоплатній формі населенню, що більше за інших потребує соціального захисту від держави. Підставою для отримання такого типу житлової площі є наявність договору найму. Термін дії договору обмежений певним строком. Таким чином, такі оселі неможливо приватизувати, продати, чи якимось іншим чином відчужити, або ж передати в заставу [5]. Отже, отримавши соціальну оселю, особа, якій надане таке житло, володіє лише правом тимчасового користування ним відповідно до договору найму, який повинен бути укладеним між наймачем соціальної оселі та відповідним органом місцевого самоврядування.

Доступне житло - це оселі, що будуються 3 допомогою державних субвенцій, пільгових іпотечних кредитів. Така категорія житла може надаватися за певних умов. Такими $\epsilon$ : сплата споживачами визначеної величини внеску, а також виконання кредитних зобов'язань вже після заселення ними в оселю під невеликий відсоток впродовж тривалого терміну. Таким чином, доступні оселі будуються коштами мешканців. У разі виплати в повному розмірі вартості наданого житла, воно переходить у власність цих мешканців [5]. 
Ми вважаємо таке розділення дефініцій вірним та корисним для теоретичного усвідомлення державного регулювання в будівництві соціального житла.

Державне регулювання інвестиційним процесом у будівництві соціального житла - відкрита система, яка має взаємозв'язки з усіма його учасниками та середовищем. Його варто досліджувати як цілісну систему, що охоплює такі підсистеми як: передпроектна, проектна, планова, експлуатаційна, будівельна комплектація, посередницька, фінансова. Кожна 3 них $\epsilon$ економічною складовою та має певне право у виборі власного режиму функціонування. Всі компоненти цілісної системи володіють своєю цільовою функцією, системою стимулів та оцінювання ефективності режимів.

Висновки i перспективи подальших досліджень. Отже, попри відсутність в науковій літературі повного тлумачення державного регулювання інвестиційними процесами у сфері будівництва соціального житла фахівцями, узагальнивши наукові наробітки представників державного управління та економіки 3 приводу тлумачення ключових понять, визначимо державне регулювання інвестиційними процесами у сфері будівництва соціального житла як: сукупність інструментарію впливу, який допомагає відповідним органам держави, керуючись законодавчими нормами та в межах своєї компетенції здійснювати регулювання механізмами функціонування системи соціально-економічних відносин з метою розширення відтворення соціального житлового фонду. Таке визначення, на нашу думку, $\epsilon$ доречним для теоретичного усвідомлення поняття державного регулювання інвестиційними процесами у сфері будівництва соціального житла, а також вирізняється новизною та підходом до його трактування.

Незважаючи на наявну кількість наукових досліджень 3 питання дослідження концептуальних засад державної інвестиційної політики, проблема державного регулювання інвестиційних процесів у сфері будівництва соціального житла залишається й сьогодні актуальною для подальших досліджень.

\section{Лimepamypa:}

1. Музиченко Т. О. Інвестиції та інвестиційна діяльність: понятійний апарат [Електронний ресурс] / Т. О. Музиченко // Сталий розвиток економіки. - 2014. - № 3. C. 161-167. Режим доступу: http://irbis-nbuv.gov.ua/cgibin/irbis_nbuv/cgiirbis_64.exe?C21COM=2\&I21DBN=UJRN\&P21DBN=UJRN\&IMAGE_FI LE_DOWNLOAD=1\&Image_file_name=PDF/sre_2014_3_28.pdf.

2. Ковалевська О. П. Форми й методи державного регулювання ринку житла [Електронний ресурс] / О. П. Ковалевська // Науковий вісник Академії муніципального управління. Серія: Управління. - 2013. - № 1. - С. 84-94. Режим доступу: http://irbisnbuv.gov.ua/cgi-

bin/irbis_nbuv/cgiirbis_64.exe?C21COM=2\&I21DBN=UJRN\&P21DBN=UJRN\&IMAGE_FI LE_DOWNLOAD=1\&Image_file_name=PDF/Nvamu_upravl_2013_1_13.pdf. 
3. Кравчун О. С. Механізми державного регулювання інвестиційної діяльності в Україні [Електронний ресурс] / О. С. Кравчун // Теорія та практика державного управління. - 2012. - № 3. - с. 328. Режим доступу: http://irbis-nbuv.gov.ua/cgibin/irbis_nbuv/cgiirbis_64.exe?C21COM=2\&I21DBN=UJRN\&P21DBN=UJRN\&IMAGE_FI LE_DOWNLOAD=1\&Image_file_name=PDF/Tpdu_2012_3_46.pdf.

4. Юр'єва Л. Ю. Правове регулювання соціального житла в системі соціального захисту [Електронний ресурс] / Л. Ю. Юр'єва // Актуальні проблеми права: теорія і практика. - 2013. - № 27. - С. 610-618. Режим доступу: http://irbis-nbuv.gov.ua/cgibin/irbis_nbuv/cgiirbis_64.exe?C21COM=2\&I21DBN=UJRN\&P21DBN=UJRN\&IMAGE_FI LE_DOWNLOAD=1\&Image_file_name=PDF/app_2013_27_82.pdf.

5. Непомнящий А. М. Перспективы строительства доступного жилья в Украине [Електронний ресурс] / А. М. Непомнящий // Будівельні конструкції. - 2014. - № 81. C. 45-52. Режим доступу: http://irbis-nbuv.gov.ua/cgibin/irbis_nbuv/cgiirbis_64.exe?C21COM=2\&I21DBN=UJRN\&P21DBN=UJRN\&IMAGE_FI LE_DOWNLOAD=1\&Image_file_name=PDF/buko_2014_81_8.pdf.

\section{References:}

1. Muzychenko T. O. (2014). Investytsii ta investytsiina diialnist: poniatiinyi aparat [Investments and investment activity: a conceptual apparatus]. Stalyi rozvytok ekonomiky - Sustainable economic development, 3, 161-167. Retrieved from: http://irbis-nbuv.gov.ua/cgibin/irbis_nbuv/cgiirbis_64.exe?C21COM=2\&I21DBN=UJRN\&P21DBN=UJRN\&IMAGE_FI LE_DOWNLOAD=1\&Image_file_name=PDF/sre_2014_3_28.pdf [in Ukrainian].

2. Kovalevska O. P. (2013). Formy y metody derzhavnoho rehuliuvannia rynku zhytla [Forms and methods of state regulation of the housing market]. Naukovyi visnyk Akademii munitsypalnoho upravlinnia. Seriia: Upravlinnia - Scientific bulletin of the Academy of Municipal Administration. Series: Management, 1, 84-94. Retrieved from: http://irbisnbuv.gov.ua/cgi-

bin/irbis_nbuv/cgiirbis_64.exe?C21COM=2\&I21DBN=UJRN\&P21DBN=UJRN\&IMAGE_FI LE_DOWNLOAD=1\&Image_file_name=PDF/Nvamu_upravl_2013_1_13.pdf [in Ukrainian].

3. Kravchun O. S. (2012). Mekhanizmy derzhavnoho rehuliuvannia investytsiinoi diialnosti v Ukraini [Mechanisms of state regulation of investment activity in Ukraine]. Teoriia ta praktyka derzhavnoho upravlinnia - Theory and practice of public administration, 3, 328. $\quad$ Retrieved from: http://irbis-nbuv.gov.ua/cgibin/irbis_nbuv/cgiirbis_64.exe?C21COM=2\&I21DBN=UJRN\&P21DBN=UJRN\&IMAGE_FI LE_DOWNLOAD=1\&Image_file_name=PDF/Tpdu_2012_3_46.pdf [in Ukrainian].

4. Yurieva L. Yu. (2013). Pravove rehuliuvannia sotsialnoho zhytla v systemi sotsialnoho zakhystu [Legal regulation of social housing in the social protection system]. Aktualni problemy prava: teoriia i praktyka - Topical problems of law: theory and practice, 27, 610-618. Retrieved from: http://irbis-nbuv.gov.ua/cgibin/irbis_nbuv/cgiirbis_64.exe?C21COM=2\&I21DBN=UJRN\&P21DBN=UJRN\&IMAGE_FI LE_DOWNLOAD=1\&Image_file_name=PDF/app_2013_27_82.pdf [in Ukrainian].

5. Nepomnyaschiy A. M. (2014). Perspektivyi stroitelstva dostupnogo zhilya v Ukraine [Prospects for the construction of affordable housing in Ukraine]. Budivelni konstruktsii - Building structures, 81, 45-52. Retrieved from: http://irbis-nbuv.gov.ua/cgibin/irbis_nbuv/cgiirbis_64.exe?C21COM=2\&I21DBN=UJRN\&P21DBN=UJRN\&IMAGE_FI LE_DOWNLOAD=1\&Image_file_name=PDF/buko_2014_81_8.pdf [in Russian]. 